This item was submitted to Loughborough's Research Repository by the author.

Items in Figshare are protected by copyright, with all rights reserved, unless otherwise indicated.

\title{
The crafting of a Paradox: Schengen inside and out
}

\section{PLEASE CITE THE PUBLISHED VERSION}

https://doi.org/10.1504/IJMBS.2020.108684

\section{PUBLISHER}

Inderscience

VERSION

AM (Accepted Manuscript)

\section{PUBLISHER STATEMENT}

This paper was accepted for publication in the journal International Journal of Migration and Border Studies and the definitive published version is available at https://doi.org/10.1504/IJMBS.2020.108684

\section{LICENCE}

CC BY-NC-ND 4.0

\section{REPOSITORY RECORD}

Oelgemoller, Christina, Leonie Ansems de Vries, and Kees Groenendijk. 2020. "The Crafting of a Paradox: Schengen Inside and Out". Loughborough University. https://hdl.handle.net/2134/9948617.v1. 
Title

The crafting of a Paradox: Schengen inside and out

\section{Authors}

Christina Oelgemöller ${ }^{1}$, Leonie Ansems de Vries ${ }^{2}$, and Kees Groenendijk ${ }^{3}$

\section{Abstract}

There is now a large literature discussing 'Fortress Europe' and the character of the Schengen area, especially how it has established freedom of movement inside at the expense of easy access from the outside. This article challenges this metaphor by going back to the early negotiations around Schengen and shedding light on some of the concerns raised at the time regarding 'compensatory measures', the un/desirable and technological solutions. We do so through a genealogical reading of documents from two different but related archival sources that allow insight into the perceptions of policy-makers at the time when Schengen was negotiated, now that these documents have become partially accessible. We show that consensus around the freedom and regulation of movement internally and control of access at the boundaries was crafted simultaneously - rather than as a 'compensatory measure' - and in the context of efforts to identify the un/desirable and find technological solutions to the 'problem' of free movement. We also discuss how this has transformed our understanding of the place and meaning of freedom of movement such that today it is both taken for granted and under attack.

Key words: Schengen, freedom of movement, securitisation, migration, technology, genealogy 


\section{Introduction}

Today in the European Union, freedom of movement is both taken for granted and increasingly under attack with calls for its reversal by sections of society as much as by governments. At the core of this contention are questions over security, such as the perceived threat of unsolicited in-migration of people seeking protection and acts of terror committed within European territories, as well as questions over belonging and identity. The notions of 'Fortress Europe' and 'migration crisis' have become important tropes in these debates. This article challenges these notions by going back to the early negotiations leading to the Schengen agreement and shedding light on some of the concerns raised at the time regarding 'compensatory measures', the un/desirable and the development of technology-based 'solutions'.

The Schengen Agreement (Schengen I) of 14 June 1985 endorses freedom of movement as a public good. In the second half of the 1980s, Schengen I was communicated as a generous and vital move enabling openness between European states. This is a visionary idea, especially in the context of the continent's history and xenophobic tendencies. However, as we show in the article, the linking of crime/terrorism with the international mobility of (certain) people and the development of border control technologies were concomitant with the openness introduced by 'The Convention implementing the Schengen Agreement' (Schengen II) in June 1990. What have been called 'compensatory measures' are to enable the wanted mobility of goods, services and people inside, whilst at the same time making sure that unwanted mobility is controlled, if not eliminated (Amoore, 2006; Broeders and Hampshire, 2013). 
Schengen debates did not take place in a vacuum; since the early 1980 s, similar discussions around controlling unwanted mobility had been held by the Intergovernmental Consultations on Migration, Asylum and Refugees (IGC). These discussions overlap with processes of negotiation of Schengen and, much like today, in these debates the movement of people seeking refuge in Europe was framed as a 'crisis' of mobility (Ansems de Vries and Guild, 2019). Drawing on the most recent 'crisis' as a justification, some European governments have begun to undermine Schengen principles of openness by re-introducing internal controls of borders much more permanently than the agreement allows for. Measures also include a move towards interoperability of data systems, which affects all third-country nationals (Carrera and Stefan, 2018; cf. Bigo, this issue).

Starting from today's conception of a perceived 'crisis' and the metaphor of 'Fortress Europe', we turn to the early Schengen and IGC archives to read these genealogically and to ask what the conditions of possibility are for today's situation. Our key question is, therefore: What can early discussions around Schengen tell us about the management of mobility in Europe today? Specifically, we discuss three concerns regarding freedom/management of mobility raised at the time. The first is that of 'compensatory measures': the 'external' management of movement required to enable freedom of movement 'internally'. The second, and related, concern regards defining the 'undesirable foreigner'. The third is the effort to find technological solutions to the 'problem' of freedom of movement. These are, of course, not the only questions raised at the time but they are significant for understanding the questions asked and 'solutions' proposed today. Our own concern in asking 
these questions is not merely academic but also political: It is grounded in a profound unease about the violence of migration management, as we discuss in more detail in our other work (Ansems de Vries and Guild, 2019; Oelgemöller, 2017).

Our main argument is that, from its inception, the spirit of generosity that informed the development and institution of the Schengen Agreements went hand-in-hand with the regulation of mobility. This is partly due to the ways in which IGC and Schengen debates informed each other. The contribution of this claim to existing debates on the development of the freedom of movement is twofold: firstly, it offers a critique of literature that revolves around notions of 'crisis' and 'Fortress Europe'; secondly, it shows that the regulation of mobility is not a 'compensatory measure' in response to freedom of movement. Rather, the tension between generosity and regulation is what constitutes 'freedom of movement' in the European context.

Thus, we argue that what came to be termed 'compensatory measures' were part of the crafting of Schengen and therefore not 'compensatory' but rather the development of a co-constitutive paradox of freedom/securitisation of mobility. Moreover, Schengen negotiators argued for 'compensatory measures' not only to ensure 'national security' - i.e. concerning cross-border movements from outside the Schengen Area - but also in reaction to a concern with 'public order', i.e. intra-Schengen mobility. This means, secondly, that it is not so much a matter of building a fortress as of the ability to 'secure' freedom of movement. Technological developments play a significant role in these processes. Whilst the development of border technologies, including databases, were still in their infancy at the time 
Schengen was negotiated, these developments were about to accelerate dramatically and, crucially, technological 'solutions' had become imaginable. We suggest that it is partly due to the rapid development of technology and the understanding of technology as 'solution' to the 'problem' of movement, that the productive tension between the spirit of generosity and the securitisation/management of mobility is pushed towards the latter, yet without erasing the former. This co-constitutive tension continues to be (re)produced today.

We develop our argument by drawing on documents from two different but related archives, that of the IGC and a collection of Schengen documents, which combines governmental documents mainly from the perspective of Dutch civil servants and sources held by the Dutch government. We first introduce the archives and outline our genealogical approach to reading the documents. We then discuss the current issue of freedom/securitisation of mobility in Europe and challenge the notion of 'Fortress Europe' to describe this condition. This is followed by our reading of the IGC and Schengen archives in relation to the questions of compensatory measures, un/desirability and technological solutions.

\section{Reading the archives}

We draw on two archival collections. The first is composed of government documents collected over time and recently corroborated by documents held at the Dutch National Archive that focus on the unfolding negotiations around the Schengen agreement. Many of these documents have only recently 
become publicly available, whilst other documents remain inaccessible (e.g. files held by the Dutch Ministry of Foreign Affairs). Of particular interest are boxes with a rather chaotic collection of hundreds of documents of the Ministry of Justice (MoJ) covering the period 1984-1987 and well-ordered and selected documents of the Ministry of Economic Affairs (MEZ) covering the years 1984-1992. The MEZ files, the ministry responsible for Benelux and hence for the coordination of Schengen until 1992, portray the process of preparation for meetings of the Dutch Council of Ministers between 1985 and 1992. At least twice a year this ministry would present an overview of the developments updating the council. Most of the documents date from 19841987; only a few relate to $1988-1992$. Whilst the Dutch perspective dominates in these documents, confidential messages from the Dutch embassies in Bonn and Paris offer an insight into German and French perspectives.

The MoJ files seem to be mostly the collection of Mr. T.F.A. (Tycho) Huijts, a MoJ civil servant and one of the main Dutch Schengen negotiators. These documents contain a selection of discussions in the Dutch Council of Ministers, letters from one Dutch minister to another, coded messages from the Dutch embassies in Bonn, Paris and Brussels on negotiations and diplomatic moves, as well as reports from border guards and local police on the first effects of Schengen in practice, alongside handwritten comments by MoJ officials. The evolution of the 1985 Agreement can be followed on the basis of several drafts. Focusing on these Dutch files offers a particular perspective on Schengen processes rather than an account of the negotiations as a whole. Yet, the Dutch played an important role in the 
development of Schengen and their concerns resonate with those raised by other negotiators, as is also corroborated by our other archival research.

The second archive was compiled by Jonas Widgren, a high ranking Swedish civil servant seconded to the United Nations High Commissioner for Refugees (UNHCR), who is credited with having given birth to the IGC after a decade of discussing what was in the early and mid 1980s perceived to be an 'asylum crisis' in Western Europe. ${ }^{4} \mathrm{He}$ made his personal archive available to Sharon Stanton-Russell, formerly MIT and Charles Keely, formerly Georgetown University, in order to allow research on the governance of migration at the time. ${ }^{5}$ The documents, mainly written in English, German and French, and covering the period between 1982 and 1992, cover speeches, memoranda of understanding, plans of action, resolutions, agenda for meetings, minutes of meetings, background documents etc. This documentation was produced for and during ad hoc meetings in which government ministers of participating countries, as well as government operational and technical experts participated. Officials attend IGC meeting in 'private' capacity; to exchange ideas rather than to make decisions. The meetings were, and still are, not open to scrutiny even though they are essential for doctrine formation in other fora. Widgren's personal archive contains a only selection of IGC documents, reflecting what he considered relevant as first coordinator of the IGC.

We approach these documents genealogically. Inspired by Foucault's notion of genealogy as a history of the present - to remember what is forgotten; to unsettle what is taken for granted -, we are interested in the conditions of possibility through which a particular conception of freedom of movement has both become naturalised and is being challenged. Oelgemöller, following 
McNay (1994), describes genealogy as an analysis of discontinuous and divergent emergences,

it is knowledge of the past conceptualized as narrative and a perspective which lays bare how this knowledge is used tactically today. ... The themes through which we understand our world are products of practices that have as much to do with power as with knowledge; thus genealogy is the study of the (small) practices/events that give rise to the taken-for-granted 'realities' of our society (Oelgemöller, 2017:16).

For instance, how has the securitisation of mobility come to be understood as a necessary 'compensatory measure' - as something that secures freedom of movement - when such mechanisms were present from the start and integral to the construction of this freedom? That is, what has been conceived of as 'freedom of movement' has been bound up with the production of a regulatory framework (Foucault, 2007; Foucault, 2010; Ansems de Vries, 2016).

Genealogy is episodic: it does not aim to describe the past in its entirety; instead the focus is on particular moments and ruptures that are crucial to understanding what is emphasised as problematic in the present. This is how we read the two archives, which are themselves disparate and incomplete, having been compiled by those who participated in discussions and negotiations on freedom/security of mobility. By reading these documents side-by-side, we gain insight into what the participants judged to be important, and the - similar and different - questions and concerns raised at the time in order to shed light on the paradox of freedom/security of mobility today. 


\section{'Fortress Europe' and the freedom/securitisation of mobility}

The notion of 'Fortress Europe' (Geddes, 2000; Den Boer, 1995) has become a popular term to describe the securitisation, militarisation and externalisation of EU borders, which have made the Mediterranean into a deadly borderzone for people seeking refuge. Whilst a useful metaphor in some ways, it is problematic in at least two respects: it fails to account for the selective openness of borders and overlooks the 'internalisation' of borders. Thus, firstly, the fortress metaphor obfuscates the selective openness of EU borders (Houtum and Pijpers, 2007). Europe's national bureaucracies have been forthcoming in facilitating access and movement of desired third-country nationals, including but not limited to highly skilled migrants. Relatedly, the metaphor of fortress 'forgets' the history of Schengen, which has enabled freedom of movement, albeit only for some.

Secondly, the fortress metaphor implies that controls are directed towards the outside only. As far back as 1991, Bunyan warned of the problematic nature in which 'freedom of movement' was conceived: “...behind these [European] formal institutions lurk the beginnings of another state apparatus, made up of ad hoc and secretive bodies and separate inter-governmental arrangements, which reflects the repressive side of European political development and is largely unaccountable and undemocratic in its workings" (Bunyan, 1991:19). He shows how most of those informal arrangements were country-driven expressions of fear, including of British government officials even though they are not party to the Schengen agreement. These fears - e.g. over 'Euroscroungers' abusing social benefit provisions; the loss of control of 
borders in the context of an 'asylum crisis'; and, home-grown crime - justified internal bordering practices. Kofman and Sales (1992) show how this creation of an inside/outside dichotomy not only problematically conflates citizenship and ethnicity such that new boundaries are created but also, and more importantly, how these boundaries negatively affect particular groups of people in ways that often remain invisible, such as legally residing 'nonEuropean' women.

The imposition of internal borders has manifested with respect to the Schengen Border Code, such that today the European Commission - together with national units in Member States - routinely operate data systems and propose new instruments. Member States retain considerable competences in this area, as is particularly pertinent in the context of the Schengen Border Code, which grants Member States the power to temporarily and unilaterally re-introduce controls at internal borders. As indicated above, in 2015, a number of states re-introduced controls at sections of their internal borders and continue to operate these controls. The European Commission has at best marginal control on the use of these competences (Guild, et al., 2015 and 2016; Barbero 2018; Evret, et al., 2018).

We agree with this scholarship that Europe is not simply becoming a 'fortress'. Rather, freedom of movement and bordering practices operate selectively and on the basis of a productive tension, or co-constitution, between freedom and control, with diverging effects on different groups of people. Yet, insofar as the notion of 'fortress' conjures up an image of an internal space that can be known, observed and managed, it resonates with efforts to create integrated data systems that allow for the large-scale exchange of digitalised data. The 
Schengen Information System (SIS), the first immigration data system, under discussion since 1988 and operational since 1995, facilitates cooperation: 27 EU states (all except Cyprus) and four non-EU states currently exchange information through SIS. The system was followed by a series of immigration data systems: Eurodac, Visa Information System (VIS), the new Exit-andEntry-Control System and the forthcoming European Travel and Authorisation System (ETIAS). These systems have gradually been opened up to police, criminal justice and intelligence authorities of participating states. In 2017, the European Commission proposed to provide for "interoperability" i.e. create links between existing EU immigration and criminal law databases (European Commission, 2017; Meijers Committee, 2018).

The EU's external borders are securitised, militarised and deadly, and part of an effort to create integrated digitalised knowledge on un/desirable mobilities. Yet, it is too simplistic to describe this as 'Fortress Europe' or indeed to argue that it has compromised Schengen in such a way that freedom of movement no longer exists. Maas, who describes Schengen as visionary because freedom of movement was interpreted as a reversal of the "historical tradition of state sovereignty" (Maas, 2005:233), points out that this is now codified as EU citizenship underwritten by a strong prohibition of discrimination. Similarly Ademmer et al suggest that Schengen states have benefitted from economic exchange as well as dropping overall crime rates due to internal cooperation (Ademmer, et al, 2015: 5). Schengen has had and continues to have horrendous effects on people seeking protection in Europe (Andersson, 2014; cf. Mc Cluskey, this issue), however, as we will discuss in the forthcoming 
sections, at its inception, it was also a laboratory for a transformative vision of freedom of movement, which came to be framed in a particular way.

\section{The Crafting of Schengen}

How did Schengen come about with respect to the concerns raised and the 'solutions' proposed to the issue of freedom of movement? We focus on three related concerns that emerged within and beyond Schengen negotiations and which remain key concerns today: The felt need to 'compensate' for free movement internally by restricting external mobility; the consequent issue of how to define which kind of mobility - or which people - are desirable and undesirable, trusted and dangerous; and, the idea that the 'solution' to these issues might be found in technology through the production of technological knowledge and data systems. In the remainder of the article, we discuss these questions through our reading of the two archives; of two sets of negotiations that simultaneously diverge from and resonate with one another. The IGC discussions show little tension among participants: its purpose was to facilitate cooperation to deal with unsolicited movement and it did so by reimagining access in terms of control both internally and externally. The Schengen negotiations show an effort to collaborate for the purpose of integration and openness, yet which was to be achieved through a transformation of what it means to do control.

At first sight, the two sets of negotiations have opposite objectives: the gradual removal of controls of movement versus the regaining of control. The primary aim of the political leaders who initiated Schengen in 1984 was to 
remove controls at the internal borders between the five participating countries (Luxemburg, The Netherlands, Belgium, France and Germany). This would give citizens of these countries the experience of a concrete advantage of the European project and would prepare for the planned internal market: cross-border travel and transport of goods and services without checks, queues, waiting and related feelings of fear and insecurity. The Schengen negotiations started with a very broad agenda, however, between 1985 and 1990 issues like VAT, customs, capital, veterinarian controls, road transport, registration of weapons and many others all disappeared from the agenda, which focussed more and more on migration and asylum as well as police and criminal justice cooperation. Schengen thus became a Justice and Home Affairs issue as other ministries lost interest and influence.

A few years earlier the same group of countries, with the addition of the UK, Denmark and Switzerland, initiated consultations within the UNHCR headquarters to address an issue of urgency: the so-called 'asylum crisis' in Western Europe. It was felt that European countries had lost control over their borders as asylum seekers arrived in and moved across the continent. The IGC was created to offer a private space to develop ways to regain control. The intention was to facilitate informal consultations among senior participants if and when this was felt to be required in order "to nurse the totality of mobility related issues" (Lopez-Pozas, IGC, 19 June 1991) and to coordinate action.

At first, these two sets of negotiations seemed to remain separate from one another, although neither occurred in a vacuum. Yet, they are linked in the sense that both the IGC and Schengen were laboratories (Johnston, 2005) for governments and law enforcement marked by the exchange of information 
and circulation of ideas through the formation of a shared discursive field. In the case of the IGC, the secrecy of debates enabled this circulation. As civil servants and enforcement officers interacted, ideas that had formed in one laboratory were carried into the other and slowly seeped into the more public and formal fora of implementation.

This reliance on informality and confidentiality to formulate emerging policy resonates with Bunyan's (1991) description early Schengen negotiations. For example, in September 1984 the Dutch government decided not to publish the detailed report on the abolition of border controls. Instead a ten-line notice on the negotiations with Germany was inserted in the Dutch Official Journal. ${ }^{6}$ The political leaders apparently sought to hide the far-reaching effects of their decision. Openness was the goal of those who negotiated Schengen, which was to be achieved through integration and collaboration, yet it sat alongside the development and transformation of what it means to do control.

\section{IGC: Dealing with unsolicited movement}

On 24 January 1985 the then High Commissioner for Refugees, Poul Hartling (Denmark), is recorded to have summarised the general position of some countries, as follows: “... in Europe today, asylum-seekers and Governments are faced with problems of such complexity that a more co-ordinated approach would seem to be required...". 7 This position was extracted during fact-finding missions in November 1984 to London, Brussels, The Hague, Bonn and Geneva. The document does not identify individual countries, beyond mentioning the above fact-finding missions, and instead refers to 
those countries collectively and geographically as of Western Europe. This refers to the countries that initiated Schengen, plus Denmark, Switzerland and the UK (although Greece and Portugal are included in some documents).

The High Commissioner notes that although asylum-seekers are distinct from other groups of people on the move, in the 'mass influx' of people, most are perceived to be socio-economic migrants. According to the figures, over 100,000 people arrived in the years 1980,1981 and $1984 .^{8}$ The issue is summarised thus:

The current problem of refugees and asylum-seekers arriving spontaneously in Western European countries, mostly from outside the region, is seen in the context of economic stringency and high rates of unemployment. ... Administrative difficulties ... have been compounded by indications that there is a rising number of asylumseekers who arrive either with fraudulent travel documents or without any documentation at all. ... There has been a general tendency for Governments to be concerned at their inability to foresee and control arrivals, $\ldots{ }^{9}$

The documents portray a remarkably homogenous conception that unsolicited movement to and across Western Europe poses two interrelated problems: control of arrival externally and control of fraud and other abuse internally. The solution to the issue, which seems to be a widely shared position, is expressed in a background document: "as a matter of principle, solutions to refugee problems should be sought in the region of origin, $\ldots . .{ }^{10}$ In a similar vein, the purpose of the IGC is seen in terms of looking for a model, for which 
“... countries concerned energetically explore all possibilities for regional solutions". 11

The focus of IGC meetings was, firstly, on breaking down the problem of protection into more concrete phenomena; and, secondly on compiling data: statistics on the 'large scale influx' and tabulated summaries on asylum procedures and socio-economic conditions of participating states. ${ }^{12}$ The IGC thus set the stage for the conceptualisation of mobility into a problem of protection (of the border and territory) and a problem of provision (of key services). ${ }^{13}$

This conceptualisation of protection betrays a suspicion that those who arrived and claimed asylum might not have the grounds to do so - at least not based on provisions in international law - and instead were 'ordinary migrants' choosing to deceive. This suspicion was informed by the assumption that people were either engaged in secondary movement - i.e. moved to Europe after having found protection in their region of origin - or it was thought they were what later came to be termed 'asylum shopping'. The latter concerns the accusation against people of moving between Western European countries to secure the best possible 'deal' for themselves. Participating states expected 'solutions' to be found in the 'region'; the focus would be on how to deal with people arriving at airports and the harmonisation of visa requirements and travel documents. ${ }^{14}$ Bringing unsolicited movement under control was a matter of tightly regulating access to the European territory, thereby keeping people in their regions of origin. However, as these ideas became practical measures, they constructed the beginnings of an 
external European border and thus produced irregular movement - and illegalised people on the move.

The issue of 'provision' was to be tackled through collection of data and exchange of information. This includes tabulated information on: status determination of asylum-seekers; duration of these procedures; procedures for dealing with 'manifestly unfounded' cases; comparisons of the socioeconomic conditions of nationals, asylum-seekers and refugees; and, compilations of numbers of foreign residents from outside Western European countries. Interestingly, one analysis of data (May, 1985) concludes that the tables "show a tendency towards a negative net migration". ${ }^{15}$ This conclusion is surprising, firstly, in light of the narrative of 'crisis' and 'having lost control'. Secondly, it is in tension with the often-repeated mantra in discussions of data collection, collation and comparison that there were vast differences in terms of what (if anything) was collected and how such data was organised, making comparison and analysis near impossible. One document recommends that "states should be encouraged to unify their recording and keeping of statistics which would ... go a long way to permit accurate analysis of refugee situations facing European governments."16

It is remarkable how diverse policies and practices such as reception, housing, education, social security and naturalisation were in 1984/85 and how swiftly thereafter they are harmonised. ${ }^{17}$ The right to work for asylumseekers seems to have been among the first casualties. What had transpired by May 1985 was an evolving sense that Western European countries needed to regain control and that this was to be achieved through closer cooperation 
via information sharing. ${ }^{18}$ At a meeting The Hague in April 1986, Virginie Korte-van Hemel, the Dutch State Secretary for Justice, puts it as follows:

Since the legalistic approach [UNHCR's insistence on compliance with International Law] has not proved to be entirely effective, it is encouraging that new approaches have also been worked out in more detail. ... The purpose of such mechanism would be to arrange concrete measures, to find concrete solutions for acute situations, where only a common effort can produce results and not unilateral action - or the lack of action - that shifts the problem from one country to another. ${ }^{19}$

The context of these concerns, and specifically that of 'secondary movement,' is the situation of Iranians who fled to Pakistan and Turkey and subsequently moved onwards to Western Europe. The working group on 'Irregular Movement of Iranian Refugees and asylumseekers [sic] from Turkey and Pakistan' was among the first IGC working groups to be established. A document, labelled secret, and most likely drafted within the IGC secretariat for the meeting on the $16^{\text {th }}$ and $17^{\text {th }}$ of April 1986, offers concrete solutions to "to prevent the irregular departure of Iranian refugees and asylumseekers [sic] from their territories to third countries" 20 - although, this line is crossed out by hand in the document. The 'solutions' include the following:

6. To that end, Turkey and Pakistan should more stringently control travel documents and visas (if required by the country or countries of transit and/or destination) upon departure ...

7. Carriers operating between Turkey and/or Pakistan and the concerned western countries should collect all passengers' travel 
documents upon boarding and hand them over ot [sic] immigration authorities upon arrival. The latter will subsequently return them to the passengers concerned. [this paragraph is hand marked with a line for emphasis].

8. Those Iranians who, upon arrival from Turkey or Pakistan, apply for asylum at the airport, may be kept there pending the finalization of their asylum-procedure in the first instance, so as to maintain the responsibility of the carrier for the return of these persons to Turkey or Pakistan. [this element of the paragraph is also hand marked with a line for emphasis] $]^{21}$.

Similarly, the Schengen documents of 1986 contain proposals for 'harmonisation measures' including visas, carrier sanctions and exchange of information to respond to the issues of terrorism, crime, drugs, weapons and 'clandestine migration'. These proposed measures, which have become an integral part of the EU border regime - harmonisation of passport and visa requirements and technologies, and the outsourcing of enforcement to third parties - illustrate the ways in which data-sharing and technology are offered as 'solutions' to the problem of identifying and managing undesirable mobility. In the IGC documents, a set of 'concrete measures' for "proceeding with individual cases" internally is listed in a preparatory fax for a meeting in December 1986 and includes: "exchange of information on the identity of asylum seekers in order to prevent them to file multiple requests"; "compatibility between data-banks concerning the legislation, the jurisprudence of the receiving countries and the general information on the 
situation in the countries of origin'; and "harmonization of general conditions for granting visas."22

This pre-occupation with the production and sharing of personal data through technology, including new technological advances, continues. The December 1986 meeting, and a next one in early 1987, make reference also to collaboration with the European Economic Community (EEC) and the Nordic Council of Ministers amongst others on the exchange and checking of information on identity, including via dactyloscopic materials, provided asylum seekers have signed a declaration agreeing to transmission of that data to guarantee the protection of personal data. ${ }^{23} \mathrm{~A}$ report in October 1987 states that participating countries were able to provide information on a monthly basis and governments wanted to invite experts to further streamline statistics for analytical reports, thus establishing an early warning system "at the beginning of next year, when computer facilities were available". ${ }^{24}$

An indication of how these questions, concerns and 'solutions' become accepted as 'knowledge' and move between fora can be found in an interim report on the IGC circulated by Jonas Widgren in December 1987. He writes: "These consultations take place in a number of fora, the most important of which are ... the States parties to the 1985 Schengen Agreement... ". ${ }^{25} \mathrm{He}$ continues:

“... a first draft directive on asylum policies, submitted by the [European] Commission, is now under circulation. However, the most conspicuous progress in the field has been made in the current negociations [sic] between the Schengen-partners (Benelux, France, Germany). The drafts presently considered excludes the idea of extra-territorial effect of negative 
decisions. ... This decision will considerably influence the discussion within the Commission ..."26

This quote both suggests the importance of the Schengen negotiations in the wider discursive field, and that the embryonic doctrine formation in the IGC discussed above feeds into wider international processes, based on visions of what Schengen is inside and out.

\section{Schengen: Productive Tensions and Fears}

Schengen was primarily a German initiative, more precisely a personal initiative of the German Chancellor Helmut Kohl. The reduction of controls at the internal borders had been under discussion in the EEC in the early 1980s both in relation to the Internal Market and as part of the Europe of the Citizens. Kohl embarked on concluding bilateral agreements on the gradual abolition of controls at the common borders with the neighbours of the Federal Republic of Germany. At the German-French summit at Rambouillet in May 1984, Kohl convinced the French President Mitterand to sign such an agreement at short notice. Within two months, the Agreement of Saarbrücken was signed between Germany and France, and two weeks later Kohl invited the prime ministers of Austria, Belgium and The Netherlands to follow this example. The three Benelux countries, having abolished controls at their internal borders in the 1960s, first had to agree on a common position on the German initiative. In the first meetings of the French-German working groups implementing Saarbrücken, French officials pressed for quick harmonisation of policies on visa and drugs. ${ }^{27}$ The French focus on those two issues 
remained during the negotiation of the Schengen agreements of 1985 and 1990.

The Netherlands Prime Minister (PM) Lubbers was positive about Kohl's project from the beginning. He overcame the hesitations within his government, especially in the Ministry of Justice responsible for immigration matters. He framed Kohl's request as a good opportunity to overcome the German opposition to removing restrictions on Dutch international transport through a system of permits and border controls. In September 1984 the Dutch government mobilised its Benelux partners. Belgium was also interested in liberalisation of control of international road transport, but insisted that discussions should also cover the Belgium-French border and, thus, should involve France as well. ${ }^{28}$

Shortly before the date of signature of the Schengen Agreement, France presented a proposal for a supplementary 'Accord de caractère confidential' on drugs policy, an indication for one of the main fears of the French government. ${ }^{29}$ Apparently, the other Schengen countries did not want to have a separate supplementary agreement. It was decided to deal with the French request and some other remaining wishes of the parties in the minutes of the signature meeting at Schengen. These minutes refer to three confidential annexes, one on immigration where the Schengen states agree to combat illegal immigration of the nationals of 39 third countries and another on security with a list of 45 (roughly the same as on the first list) countries whose nationals should be checked more thoroughly at entry for security reasons. The third confidential annex was on policies against drug trafficking ("Mesures concernant la lute contre le trafic des stupéfiant') and reflects the French 
desire that the five states would engage in an active combat of trafficking, use and distribution of drugs. The minutes and the third annex on drugs were made public in The Netherlands with the official publication of the Schengen Agreement in $1985 .^{30}$

Among civil servants of the ministries there was a clear resentment against this far-reaching project, which was parachuted by the political leaders with little prior consultation. Until May 1985 Schengen cooperation was primarily a discussion between ministers and their civil servants, however, once the agreement was signed, they actively started to work on implementation. In most Schengen states the public and parliamentary discussion on Schengen cooperation was minimal before 1988.

The Schengen documents mention few concrete expectations of negotiators; rather, they give a sense of Schengen as a vision. Importance was placed on principles such as the facilitation of free movement; bringing Europe closer to the people and European people closer together; and shaping citizens' European consciousness. In addition, they emphasise the importance of the economic benefit of reducing delays at the border and the extension of the positive experiences of the Benelux.

In a speech before Members of the European Parliament (MEPs) in December 1984 the Dutch Secretary of State mentioned removing obstacles to free movement: "My father in 1952 spend three quarters of an hour at the German-Dutch border on return from holidays and considered that perfectly normal". ${ }^{31} \mathrm{~A}$ few months later she suggested: "In the long run controlling the external borders will probably become an international task", much like the IGC was already projecting at that time. The Christian-Democratic party in 
Dutch Limburg writes to colleagues in Bonn: "People should no longer be treated with suspicion when crossing a border."32

That statement, however, was most certainly not meant to be inclusive. The fear of 'illegal immigration' was illustrated in France and The Netherlands by the arrival of increasing numbers of Tamil asylum seekers through the 'Berliner Loch' (referring to the possibility to fly to East-Berlin and pass without border control to West-Berlin and the Federal republic of Germany (FRG)), the large number of Turkish workers in Germany and the possible arrival of DDR (German Democratic Republic) citizens. 'Illegal migrants' were often seen as a burden on the social welfare system. In France the Yugoslav workers entering Italy at Triëst and then traveling to France were mentioned repeatedly. These fears resonate in today's narratives. The question of whether it will be possible to return 'illegal immigrants' to the state where they entered the Schengen area is repeatedly raised in the documents. A 1987 Benelux proposal to create a common fund to pay for the expulsion of 'illegal immigrants' and avoid the need to establish which state is responsible is rejected by the other states. ${ }^{33}$

As was the case with the IGC, Schengen negotiations also identified internal problems and fears. This includes fears of increased cross-border crime, which were often linked to the wish to improve communication and cooperation between national police and criminal justice authorities. Yet, these fears are also put into perspective in internal documents, which state that terrorists are not stopped at the border. ${ }^{34}$ Nonetheless, the ways in which such fears are grouped together means that migration, crime and terrorism become linked as issues of concern, and the 'undesirable foreigner' comes to 
be defined broadly as a third-country national who has been denied entry to one of the Schengen states.

Other problems that are foreseen include difficulties with the enforcement of legislation prohibiting the export of cultural objects and considerable loss of jobs for the border police. The Dutch and German border police forces were threatened with reductions in staff in the first years after 1985, however, after 1995, both forces succeeded in expanding their role, tasks and size. This is another illustration of the co-constitutive tension between mobility and control:

internal 'freedom of movement' has meant an expansion of bordering practices. The Dutch border police acquired new competences and technical expertise, such as IT analysis of data collected by cameras placed at the internal borders, expansion of tasks at international airports and new technologies to detect document fraud.

Another unease, which Dutch politicians and officials expressed from the start of the negotiations, later followed by their German counterparts, was that the abolition of controls on persons at the internal Schengen borders would raise a demand for internal controls within the country and the obligation to carry an ID. ${ }^{35}$ Here, we see that the paradox of facilitating freedom of movement through the expansion of bordering also operates internally and affects citizens of Schengen countries, too. Despite strong reservations about ID cards in the Netherlands - the obligation to carry an ID during the World War Two (WWII) German occupation had made it a political taboo -, they were introduced in Dutch legislation in 1994, shortly before the Schengen Information System (SIS) became operational. 
Politicians and civil servants also feared public opposition to their vision and plans, and consciously played down the scope and effects of the measures. Whereas internal documents clearly stated the aim of the complete abolition of controls at the internal borders, public statements described the 'reduction' of border controls and the 'facilitation' of border crossings. At first, this 'facilitation' is said to apply only to the German-French or Dutch-German border and to nationals of the concerned states; later on, it is said to cover all nationals of EEC Member States. That the abolition of border controls would apply to all persons crossing internal borders - including third country nationals - is only gradually acknowledged. Yet, a few politicians do note this as one of the positive effects of Schengen prior to the signing of the 1985 agreement. ${ }^{36}$

The downplaying of the scope and effects of Schengen was motivated by fears of 'illegal migration', increased cross-border crime, drugs trafficking and threats to national security. In response, a note prepared by the Ministry of Justice and discussed in the Dutch Council of Ministers in November 1984 argued that the development of 'compensatory measures' at the time of the abolition of internal borders in the Benelux should be sufficient to address the fears without undermining the visionary aims of Schengen. Yet, in the documents of the Dutch archives there is no mention of the fact that borderless movement within the Benelux had been possible without compensatory measures between 1962 and 1984 .

\section{Technical 'Solutions': Integrating Data Systems}


The concerns regarding 'compensatory measures', un/desirable mobility and technological solutions come together in the development of the SIS. At the first meetings of the German-French working groups commissioned with the implementation of the Saarbrücken Agreement in the second half of 1984 it was agreed that in the short term the German Bundeskriminalamt and the French Direction centrale de la police judiciaire would exchange information on persons directly. The aim was to exchange lists of wanted persons and 'undesirable foreigners' and to arrive at reciprocal recognitions of national arrest warrants. The Working Group Police, preparing the documents for the negotiations with the Benelux countries in February 1985, decided to ask advice of the national French and German data protection authorities on the conditions for exchange of data on wanted persons. Due to 'technical obstacles' it was not possible to link the German and French databases. Hence it was decided 'to exchange magnetic tapes between the two national services, but this could probably not be realised before 1986'. In the meantime only data on stolen cars and weapons would be exchanged. ${ }^{37}$

The desirability of linking digital databases was under discussion at the same time at the Dutch Ministry of Justice. In December 1985 the Schengen ministers agreed to merge the national lists of 'undesirable foreigners', by communicating the national lists to the other Schengen partners. In 1987 the ministers decided that it would be an essential condition for the transfer of controls from the internal to the external Schengen borders to build a common database and network. ${ }^{38}$ The first draft treaty clauses on SIS related both to the exchange of digital and non-digital information. At the end of 1987 it became clear that building the SIS would take several years and that the 
results of the feasibility study on SIS would not be ready before the end of 1988.

The Dutch proposal to give local immigration authorities access to the proposed system was accepted. In addition, the Dutch successfully opposed the German proposal that third-country nationals could be registered in SIS not only on public order offenses but also after refusal of an asylum request. ${ }^{39}$ Yet, this did not stop Germany from registering thousands of failed asylum seekers once SIS became operational. This practice was only terminated after the French Conseil d'État repeatedly held it in violation of the Schengen Implementing Agreement (Brouwer, 2008). ${ }^{40}$ Germany did considerably contribute to the provisions on data protection, which provided the legal basis for the French court's ruling.

The 1985 Schengen Agreement makes no mention of data systems. Prior to and during the negotiations of the 1985 and 1990 agreements, officials of the Schengen states discussed the exchange of written and oral information as well as the possibility to exchange magnetic tapes between the Bundeskriminalamt (BKA) and their colleagues in Paris. They envisaged the possibility that new technologies for storage and exchange of large amounts of digital data might become available, however, they seriously underestimated the time required to build a large and complicated data system connecting a large amount of offices in five countries and making that system operational. With this vision of possibilities in mind, officials laid down the legal basis for SIS in the Schengen Implementation Agreement of 1990, which would become fully operational only in March 1995, a few months before the $10^{\text {th }}$ anniversary of the signing of the first Schengen Agreement. As 
more sophisticated technology became available its use was increasingly framed in terms of security and the productive tension between freedom and regulation of mobility was pushed towards the latter, although never fully. This co-constitutive tension continues to be (re)produced today.

\section{Conclusion}

The conditions of possibility for the ways in which freedom of movement is both taken for granted and under attack today - e.g. through concepts such as 'migration crisis' and 'Fortress Europe' - lie in a broad, complex and discontinuous range of discourses, practices and events. In this article, we have focused on three broad questions and concerns, as articulated in the documents of the IGC and Schengen archives we studied, covering the early negotiations of both initiatives. These are, firstly, 'compensatory measures' to manage external mobility in order to enable freedom of movement internally; secondly, the need to define and identify the un/desirable; and, thirdly, the effort to find technological 'solutions' to the first two questions. We have shown that an understanding of these early questions and concerns can help shed light on the perceived polarisation of debates on the freedom/securitisation of mobility today. That is, it is less an issue of building a fortress or declaring a 'crisis' per se, and more a concern with 'securing' freedom of movement by circumscribing it through data-driven technological 'solutions' that help sift wanted and unwanted mobility and identify the 'undesirable'.

We have thus approached IGC and Schengen as laboratories for the production of knowledge and practices on the freedom/securitisation of 
mobility. Whilst the IGC discussions focused primarily on the control of unwanted mobility, the Schengen negotiations display a productive tension between, on the one hand, a vision of European freedom of movement, collaboration and integration, and, on the other, regulating what were regarded to be its unwanted effects. These tensions, which were part of the crafting of the Schengen paradox from the start, have remained prominent in the decades since the signing of the 1985 Schengen Agreement. However, the technology-based 'solutions' that have been proposed and implemented over the years have meant that these tensions are increasingly 'resolved' in favour of control. Thus, we suggest that it is in part due to the rapid development of technology in the past three decades that the early articulations of technology-based 'solutions' around collecting, exchanging and integrating information and information systems have shifted the spirit of generosity and openness some way towards securitisation and management of mobility.

The documents of the early IGC and Schengen negotiations show practices of power and knowledge as circulatory and meditating forces in a number of ways. Firstly, as outlined above, the efforts to 'resolve' the productive tensions into something more tangible and certain can be seen in the ways in which technology becomes employed to produce a particular conception - and identity - of the un/desirable foreigner. However, as we have shown, this was an unforeseen effect of rapid technological advances. Secondly, it can also be observed in the ways in which governments - in a dominant power/knowledge position - sought to craft and limit the public narrative by not communicating the full scope and effects of the Schengen Agreement. It seems that it was out 
of fear of a conservative backlash that the generosity driving Schengen to create a Europe of the Citizen was not fully communicated. This approach - in a broader context in which human mobility is considered a 'problem' - might have been another contributing factor to the emphasis on security over freedom of mobility that we see also today. Despite its spirit of openness and generosity, as a laboratory for the production of knowledge, Schengen is today much more easily recognised as being mostly concerned with un/wanted movement and the un/desirable foreigner. We have argued, however, that the co-constitutive tension between freedom/securitisation of mobility through which Schengen emerged continues to be (re)produced in various forms today. 


\section{Bibliography}

Ademmer, E., Toman Barsbai, Matthias Lücke, and Tobias Stöhr. 2015. "30 Years of Schengen: Internal blessing, external curse?" Kiel Policy Brief No 88 Amoore, L. 2006. "Biometric borders: Governing mobilities in the war on terror" Political Geography 25(3): 336-351

Andersson, R. 2014. Illegality, Inc.: clandestine migration and the business of bordering Europe. Oakland: University of California Press

Ansems de Vries, L. 2016. "Politics of (In)visibility. Governance-Resistance and the Constitution of Refugees in Malaysia", Review of International Studies, 42(5): 876-894

Ansems de Vries, L and Elspeth Guild. 2019. "Seeking Refuge in Europe: Spaces of Transit and the Violence of Migration Management", Journal of Ethnic and Migration Studies 45(12): 2156-2166

Barbero, I. 2018. "The European Union Never got Rid of Its Internal Controls." European Journal of Migration and Law 20(1): 1-27

Broeders, D. and James Hampshire. 2013. "Dreaming of Seamless Borders: ICTs and the Pre-Emptive Governance of Mobility in Europe" Journal of Ethnic and Migration Studies 39(8): 1201-1218

Brouwer, E. 2008. Digital Borders and Real Rights. Leiden: Brill/Nijhoff Bunyan, T. 1991. "Towards an authoritarian European state." Race \& Class 32(3): 19-27 
Carrera, S. and Marco Stefan. 2018. "The Future of the Schengen Area: Latest Developments and Challenges in the Schengen Governance Framework since 2016". Policy Paper. Brussels: CEPS Special Reports

Ceccorulli, M. March 2018. "On protection and Justice: The Proposals for Reform of the Common European Asylum System" Globus Research Paper $4 / 2018$

Den Boer, M. 1995. "Moving between bogus and bona fide: the policing of inclusion and exclusion in Europe", in Miles, R. and Dietrich Thraenhardt (ed.). Migration and European integration: The dynamics of inclusion and exclusion, London: Pinter Publishers. pp.92-111

European Commission. 2017. Proposal for a Regulation of the European Parliament and of the Council on establishing a framework for interoperability between EU information systems (police and judicial cooperation, asylum and migration) 12 December 2017. COM (2017) 794

Evrard, E., Birte Nienaber, and Adolfo Sommaribas. 2018. "The Temporary Reintroduction of Border Controls Inside the Schengen Area: Towards a Spatial Perspective." Journal of Borderlands Studies 1-15

Foucault, M. 2007. Security, Territory, Population, Lectures at the Collège de France 1977-78, Basingstoke: Palgrave Macmillan

Foucault, M. 2010. The Birth of Biopolitics. Lectures at the Collège de France, 1978-79, Basingstoke: Palgrave Macmillan

Geddes, A. 2000. Immigration and European Integration: Towards Fortress Europe? Manchester University Press 
Guild E., Evelien Brouwer, Kees Groenendijk and Sergio Carrera. December 2015. What is happening to the Schengen borders? CEPS Paper in Liberty and Security No. 86

Guild, E. 2016. Internal Borders in the Schengen Area: Is Schengen CrisisProof? Study (PE 571 356), Brussels: LIBE Committee of the European Parliament

Johnston, H. and Associates. 2005. "IGC: An Assessment of Twenty Years" unpublished and unfinished document www.iom.int/jahia/webdav/.../IGC/2005-IGC-20-Years-Assessment.pdf (accessed September 2011)

Kofman, E. and Rosemary Sales. 1992. "Towards Fortress Europe?." Women's Studies International Forum, 15(1): 29-39

Maas, W. 2005. "Citizenship, Free Movement, and EU Enlargement." Jean Monnet/Robert Schuman Paper Series 5(34): 1-15

McNay, L. 1994. Foucault: A critical introduction. Cambridge: Polity Meijers Committee. 2017. Comments on the Proposal for a Regulation of the European Parliament and of the Council on establishing a framework for interoperability between EU information systems (police and judicial cooperation, asylum and migration) 12 December 2017. COM (2017) 79419

Oelgemöller, C. 2017. The Evolution of Migration Management in the Global North. Routledge

Van Houtum, H. and Roos Pijpers. 2007. "The European Union as a gated community: the two-faced border and immigration regime of the EU." Antipode 39(2): 291-309 
1 Loughborough University

2 King's College London

${ }^{3}$ Radboud University Nijmegen

${ }^{4}$ For a broader historical analysis of the 1980s and the substantial changes in the policy thinking concerning international mobility at the time see: Oelgemöller 2017.

5 Friedrich Loeper, a former coordinator, gave verbal acknowledgement of this on two occasions, the last during the Global Forum for Migration and Development on 1 December 2011.

${ }^{6}$ Staatscourant 24 September 1984.

7 'Consultations on the Arrivals of Asylum Seekers and Refugees in Europe', UNHCR, 29 April 1985; $\mathrm{HCR} / \mathrm{CAE} / 85 / 2$, page 1

8 ibid, page 5

9 ibid. page 6

${ }^{10}$ no author, 20.05.85, document: WC/emj

${ }^{11}$ Anita Gradin, Cabinet Minister, Sweden, Opening Address, 25 November 1985, page 4

12 no author, 3.5.85, document: WC/emj

${ }^{13}$ no author, no date, Task Force on the European Protection Seminar 1985, Minutes of meetings held on 2 and 5 November [1984], Annex I

${ }^{14}$ no author, no date, Task Force on the European Protection Seminar 1985, Minutes of meetings held on 2 and 5 November [1984], Annex I

15 no author, 24 May 1985, document AD/MP/mms

${ }^{16}$ no author, no date, Arrivals of Asylum Seekers and Refugees in Europe, UNHCR Policy Statement

17 no author, 22.5.85, document MP/dm, Annex II

${ }^{18}$ Anita Gradin, Cabinet Minister, Sweden, Opening Address, 25 November 1985

19 Opening Statement by Mrs Virginie Korte-van Hemel, State Secretary for Justice at the informal meeting on asylum seekers and refugees in Europe, The Hague, April 16, 1986

${ }^{20}$ no author, hand-written date 16-17/4 1986, no document reference number, page 2 
21 ibid, pages 2, 3

22 Permanent Mission for Switzerland, Geneva, 1986-12-05, informal meeting of representatives of the governments, tentative catalogue of possible measures, no document number, Annex 1 pages 2,3

${ }^{23}$ no author, 29.1.1987, Working paper, 5. Exchange of personal data, Informal consultations

Gerzensee 1987, page 6, 7

${ }^{24}$ no author, 2 October 1987, Confidential Report, document number C/ft, page8, cover letter by Jonas Widgren, Coordinator of the IGC dated 28 October 1987

25 Jonas Widgren, 7 December 1987, Confidential, The informal consultations: interim report December 1987, UNHCR document number 391.84, page 1

${ }^{26}$ ibid, page 3

${ }^{27}$ Code message from Dutch embassy to Ministry of FA of 1 September 1984, Benelux document P/DIV (84)131 of 23 November 1984 and code message of Dutch embassy in Paris to Ministry of FA of 6 December 1984.

${ }^{28}$ Internal note of Head of Alien's Department of Dutch Ministry of Justice of 13 July 1984 and draft letter of that department to Ministry of FA of 21 September 1984.

${ }^{29}$ Confidential Note of the French embassy in Brussels of 22 May 1985, Benelux document BNL-DF/pol. (85)5 of 28 May 1985.

${ }^{30}$ Tractatenblad 1985, no. 102, p. 11-13, only Dutch language version published.

${ }^{31}$ Code message of Dutch embassy in Paris to Ministry of FA of 16 October 1984.

${ }^{32}$ Letter of 27 March 1984 to Dr. Dregger leader of the CSU fraction in the Bundestag.

${ }^{33}$ Note of Ministry of Economic Affairs for Dutch Council of Ministers with a view to the meeting of Schengen Secretaries of States on 3 June 1987 and Tweede Kamer documents TK 1987-1988, 18941, no. 2

${ }^{34}$ At meeting of Benelux ambassadors at German Ministry of FA in Bonn on 30 August 1984, code message from Dutch embassy to Ministry of FA of 1 September 1984.

${ }^{35}$ In Note of Ministry of Justice of 18 September 1984 for Dutch Council of Ministers meeting on 21 September 1984, in letter of Prime Minister to his colleagues of 19 January 1985 and during the first 
discussion of the draft SIA with Dutch MPs on 29 May 1985, Tweede Kamer documents TK 18941, no. 2.

36 Tweede Kamer documents TK 1984-1985, 18941, no. 2.

37 Code message Dutch embassy in Paris to Ministry of FA of 14 February 1985

${ }^{38}$ Document SCH/C (87) 4 of 12 May 1987, p. 7

${ }^{39}$ Note of Dutch Ministry of Economic Affairs or 23 October 1989 preparing for the meeting of

Schengen Secretaries of State on 12 November 1989 and for the discussion with the Dutch Parliament in advance of that meeting, p. 6/7.

40 Decisions of 9 June 1999 (Forabosco), 9 July 2001 (Matumona), 11 July 2001 (Iqbal) and 15 March 2002 (Krouf); 